Dialectologia. Special issue, $\boldsymbol{V}$ (2015), 219-240.

ISSN: 2013-2247

Received 28 March 2015.

Accepted 20 June 2015.

\title{
THE ALLOMORPHS OF DIRECT OBJECT CLITIC PRONOUNS AND THEIR GEOLECTAL VARIATION IN WESTERN ASTURIAS
}

\author{
Ramón de Andrés, Fernando Álvarez-Balbuena, María Cueto, Miguel R. Monteavaro
}

\& Xosé Miguel SUÁREZ

Universidad de Oviedo

randresd@uniovi.es / balbuena@uniovi.es / cuetomaria@gmail.com /

miguelomonteavaro@hotmail.com / tapiadelfa@yahoo.es

\begin{abstract}
The subject of this contribution is the geolectal distribution of some morphosyntactic phenomena in the Eo-Navia strip, a linguistic boundary between the Galician-Portuguese and AsturLeonese domains in the westernmost side of Asturias. Those phenomena concern the $3^{\text {rd }}$ person direct object clitic pronouns and their allomorphs, conditioned by the previous phonic environment: $-r,-s,-n$ and diphthong. The data - obtained from the project ETLEN - are presented according to two options of classification and two of geolectal analysis. The two options of classification are: (1) according to the forms of the pronouns; (2) according to «existence» or «nonexistence» of pronominal variation. The two geolectal analyses are: dialectographic or «classic», with attention to the distribution of variation areas in 40 villages; and "horiometric», considering distribution of percentages of geotypological assignment (Galician-Portuguese vs. Astur-Leonese phenomena). The results show that the chosen phenomena of geolectal variation are also part of the well-known «isogloss bundle» marking the boundary between both domains.
\end{abstract}

Keywords

pronominal allomorphs, linguistic boundary, Galician-Portuguese, Astur-Leonese, horiometry 


\section{LOS ALOMORFOS DE LOS PRONOMBRES CLÍTICOS Y SU VARIACIÓN GEOLECTAL EN LA ZONA EO-NAVIA}

(ASTURIAS)

\section{Resumen}

El objeto de esta contribución es la distribución geolectal de ciertos fenómenos morfosintácticos en la franja Eo-Navia, frontera lingüística entre los dominios gallegoportugués y asturleonés la parte más occidental de Asturias. Se trata de los pronombres clíticos de 3 a persona de objeto directo y sus alomorfos, condicionados por el entorno fónico precedente: $-r,-s,-n$ y diptongo. Los datos -obtenidos por el proyecto ETLEN- se presentan según dos opciones de tipificación y según dos análisis geolectales. Las dos opciones de tipificación son: formas de los pronombres / existencia o no de variación entre formas primarias y secundarias. Los dos análisis geolectales son: dialectográfico o "clásico», con atención a la distribución de áreas de variación en el mapa, de acuerdo con 40 localidades; y horiométrica, que atiende a la distribución de porcentajes de adscripción geotipológica (fenómenos gallegoportugueses frente a asturleoneses). Los resultados demuestran que los fenómenos de variación geolectal considerados forman parte también del famoso "haz de isoglosas» que marca la frontera entre gallegoportugués y el asturleonés.

\section{Palabras clave}

alomorfos pronominales, geografía lingüística, frontera lingüística, gallegoportugués / asturleonés, horiometría

\section{Introduction}

The aim of this paper is to study the geolectal variation of the allomorphs of 3rd person direct object (DO) clitic pronouns in the transitional stretch of land between the linguistic domains of Galician-Portuguese and Astur-Leonese in the westernmost end of Asturias, in an area that will be referred to as Eo-Navia, in association with the two rivers that border it in the coastal area.

\section{State of the art}

Table 1 compares the situation of these pronouns in the Galician, Portuguese and Asturian standard models or varieties, offering an illustrative example of each. The white boxes represent the geolectal phenomena promoted by each standard model, while the greyed boxes represent those geolectal phenomena which are not 
Dialectologia. Special issue, $\boldsymbol{V}$ (2015), 219-240.

ISSN: 2013-2247

contemplated in the standard models; they are exemplified with typical short sentences. "Primary" forms are understood as those which can be found in a postvocalic context, that is, those forms that, over time, are not influenced by preceding sounds (e.g. in a proclitic position and preceded by a simple vowel); and "secondary" forms are understood to be the allomorphs originated in a conditioning context, i.e. through the influence of certain sounds over time.

\begin{tabular}{|c|c|c|c|}
\hline \multirow{4}{*}{-vowel + ... } & Portuguese & Galician & Asturian \\
\hline & \multicolumn{3}{|l|}{ PRIMARY FORMS } \\
\hline & $O, A, O S, A S$ & O, A, OS, AS & LU, LA, LO, LOS, LES \\
\hline & Sempre o faz 'He always does' & Sempre o fai & Siempre lo fai \\
\hline & \multicolumn{3}{|l|}{ SECONDARY FORMS } \\
\hline \multirow{4}{*}{$-r+\ldots$} & $(-R)+-L O,-L A,-L O S,-L A S$ & $(-R)+$ LO, LA, LOS, LAS & (-R) + LU, LA, LO, LOS, LES \\
\hline & \multirow{3}{*}{$\begin{array}{l}\text { Quer vendê-lo 'He wants to sell } \\
\text { it' }\end{array}$} & \multirow{3}{*}{ Quere vendelo } & Quier vendelo \\
\hline & & & $\begin{array}{l}\text { (-R) + LUU, LIA, LLOS, LبAS } \\
(-R)+\text { LLU, LLA, LOS, LLAS }\end{array}$ \\
\hline & & & $\begin{array}{l}\text { Quier vendello } \\
\text { Quier vendello }\end{array}$ \\
\hline \multirow{4}{*}{$-s+\ldots{ }^{*}$} & $(-S,-Z)+-$ LO, -LA, -LOS, -LAS & $(-S)+$ LO, LA, LOS, LAS & -S + LU, LA, LO, LOS, LES \\
\hline & $\begin{array}{l}\text { Isso vende-lo tu? 'Do you sell } \\
\text { that?' } \\
\text { Isso fá-lo e trá-lo 'Do it and } \\
\text { bring it' }\end{array}$ & \multirow[t]{3}{*}{ ¿lso véndelo ti? } & \multirow[t]{3}{*}{ ¿Eso viéndeslo tu? } \\
\hline & $-S+-O,-A,-O S,-A S$ & & \\
\hline & $\begin{array}{l}\text { Isso vendes-o tu? 'Do you sell } \\
\text { it?' }\end{array}$ & & \\
\hline \multirow{4}{*}{$\begin{array}{l}-n+\ldots \\
-m+\ldots\end{array}$} & $\begin{array}{l}\text {-M, nasal dipth + -NO, -NA, -NOS, } \\
\text {-NAS }\end{array}$ & $(-\mathrm{N})+\mathrm{NO}, \mathrm{NA}, \mathrm{NOS}, \mathrm{NAS}$ & $-N+L U, L A, L O, L O S, L E S$ \\
\hline & \multirow{3}{*}{$\begin{array}{l}\text { Isso compram-no lá 'They buy } \\
\text { it there' } \\
\text { Dão-nas 'They give them' }\end{array}$} & Iso cómprano alí & \multirow{3}{*}{ Eso cómprenlo ellí } \\
\hline & & $(-N)+0, A, O S, A S$ & \\
\hline & & Iso cómprano ali ** & \\
\hline \multirow{4}{*}{ oral dipth. $+\ldots$} & -dipth. +-O, -A, -OS, -AS & -dipth. + NO, NA, NOS, NAS & -dipth. + LU, LA, LO, LOS, LES \\
\hline & \multirow{3}{*}{$\begin{array}{l}\text { A canção cantei-a eu 'I sang } \\
\text { the song' } \\
\text { Levou-os no carro 'He took } \\
\text { them in the car' }\end{array}$} & $\begin{array}{l}\text { A canción canteina eu } \\
\text { Levounos no coche }\end{array}$ & \multirow{3}{*}{$\begin{array}{l}\text { El cantar cantáilu } \\
\text { La sidra bebéilo 'Drink the } \\
\text { cider' } \\
\text { Eses caxes trailes 'Bring these } \\
\text { boxes' } \\
\text { (Llevóulos no coche) }\end{array}$} \\
\hline & & -dipth + O, A, OS, AS & \\
\hline & & $\begin{array}{l}\text { A canción canteia eu } \\
\text { Levouos no coche }\end{array}$ & \\
\hline
\end{tabular}

Table 1. Allomorphs of the $3^{\text {rd }}$ person DO clitic pronouns in Portuguese, Galician and Asturian 
In general terms, Galician-Portuguese tends towards a variation of "primary" and "secondary" forms, in contrast to Astur-Leonese, which has a stronger tendency towards "unique" forms. As it can be observed, the allomorphs or "secondary" forms appear in Galician-Portuguese when the clitic pronoun $o, a$, os, as is preceded by $-r,-s$ (-z), nasal or oral diphthong.

The greyed areas highlight those phenomena that have not been recorded in the standard models, but which are still part of the geolectal reality of each territory. This refers to the absence of secondary forms in Galician-Portuguese and the presence of secondary forms in Astur-Leonese. These phenomena are exemplified with typical short sentences.

In Portuguese, the primary forms maintained in $-s+-o-a$ are typical of nonstandard spoken language (João Saramago, personal communication). In Galician, there is an absence of secondary forms after [-n] in scattered geographical points spread out throughout Galicia, as well as El Bierzo (León) and Sanabria (Zamora). In the same way, there is an absence of secondary forms in Galician, in Fisterra (West of A Coruña) and the south-western (Pontevedra) and south-eastern (Ourense) parts of Galicia (Rosario Álvarez Blanco, personal communication).

In the case of Astur-Leonese, secondary forms following $-r$ are registered in a relatively wide area of Asturias and León, most often coexisting with the primary forms. And thus, the pronouns lu la lo los las 'him, her, it, them' are transformed into Ilu -lla -llo -llos -llas or in -!lu -!!a -!los -!las.

As it is widely known, this varied allomorphic casuistry is caused by phenomena of phonetic evolution: namely assimilation amongst sounds which are in contact with the /I-/ that characterized the pronouns during a first phase common to both domains (Williams 1994: 154-158; Ferreiro 1996: 245-247). Thus, this casuistry straddles both phonetic and morphosyntactic issues.

\section{Aim of this inquiry}

From this point onward, attention will be focused on the linguistic geography that such pronominal allomorphs present in the Eo-Navia area, a transitional stretch of 
land in which a well-known isogloss bundle between the Galician-Portuguese and Astur-Leonese domains is located. To this end, the study will make use of all the geolinguistic information available up to this date, data which will be completed by the addition of the information gathered as a result of this team's project «Estudio de la Transición Lingüística en la zona Eo-Navia, Asturias (ETLEN)». ${ }^{1}$

The vast majority of available geolinguistic information about the Eo-Navia area, is accessible through dialectological works that encompass the entirety of the Galician language, such as the Atlas Lingüístico de la Península Ibérica (ALPI) (Heap 2003), the Atlas Lingüístico Galego (ALGa) (García, Santamarina \& Fernández Rei 1990, 2003; García, Santamarina \& Álvarez Blanco 1995; García, Santamarina \& González 1999; García, Santamarina, Álvarez Blanco, Dubert García \& Sousa Fernández 2005) and the Dialectoloxía da lingua galega by Fernández Rei (1990). To these, we must add the works that abridge under one single corpus the data obtained from different previous sources, such as the Diccionario de diccionarios (DdD) (Santamarina 2003) and the Diccionario general de la lengua asturiana (DGLA) (García Arias 2002-2004). Furthermore, a great number of monographs and research pieces focusing on the different speech forms in the area have been consulted (Alonso 1972-1993; Babarro Fernández 2003; Fernández Vior 1997; Frías Conde 2001; García 1983; Muñiz 1978, among others). All of these sources, variable in quantity and quality, provide a general geolectal portrait of those phenomena this paper is most interested in. The considerable amount of data obtained thanks to the above-mentioned ETLEN project, will contribute to a more complete view of the situation.

\footnotetext{
${ }^{1}$ Project ETLEN studies the border between the Galician-Portuguese and the Astur-Leonese domains attending to three different scopes: dialectographic, in line with traditional dialectology; horiometric (of a statistical nature), based on the ascription of variants according to geotypological parameters, thus obtaining a figure, which indicates the percentages of the variant in each of the villages or towns studied; and a dialectrometric approach, also statistical in nature, consisting on the cumulative measuring of the linguistic similarity/dissimilarity in the different villages and towns in the territory studied. The source of data is an in-house questionnaire based on 366 differentiating phenomena, applied to 40 villages and towns. The end result of this research will be the Atlas Lingüistico de la Zona Eo-Navia, Asturias (ATLEN), currently under preparation. More information can be found in Andrés Díaz, Álvarez-Balbuena \& Suárez Fernández (2007), Andrés Díaz \& Álvarez-Balbuena (2011), Andrés Díaz (2011, 2013), Álvarez-Balbuena García, Andrés Díaz, Suárez Fernández \& Cueto Fernández (2011), Andrés Díaz, Álvarez-Balbuena, Cueto Fernández \& Suárez Fernández $(2012,2013)$, Cueto Fernández (2012).
} 
The ETLEN questionnaire consists of 366 differential phenomena illustrated with 569 items (words or phrases). It was been applied to indigenous speakers over 65 years of age of each of the 40 chosen villages. By exceeding the aim of the research team, this questionnaire does not attend to sociolinguistic phenomena; however, the sociological diversity of the 40 villages is irrelevant.

The main aims of this inquiry are:

1. To understand with more precision the pronominal 3rd person DO allomorphs, both in their geolectal distribution as well as their formal diversity.

2. To highlight the relevance of these phenomena in the well-known isogloss bundle existing between the Galician-Portuguese and Astur-Leonese domains.

\section{Phenomena under consideration}

In the ETLEN questionnaire, the main source from which the data studied have been extracted, there are several entries which refer to the 3rd person DO clitic pronouns: three of them refer to "primary" forms; one refers to "secondary" forms preceded by verbal -r; one refers to "secondary" forms after verbal -s; and one refers to "secondary" forms after - $n$ [-n]. "Secondary" forms preceded by oral diphthong are not under consideration in this instance. These are the phenomena studied in this piece of research:

\section{Primary forms of the 3rd person masculine singular DO clitic pronoun.}

Reference example: El café que lo compre el tou fiyo 'The coffee must be bought by your son'.

2. Primary forms of the 3rd person feminine singular DO clitic pronoun.

Reference example: A casa que la compre Pedro 'The house must be bought by Pedro'.

3. Primary forms of the 3rd person masculine plural DO clitic pronoun.

Reference example: Os cochos que los compre Pedro 'The pigs must be bought by Pedro'.

4. Secondary forms of the 3rd person masculine singular DO clitic pronoun after verbal $-r$. Reference example: El coche, vendelo é el miyor que fais 'Your car, to sell it is the best thing you can do'. 
5. Secondary forms of the 3rd person masculine singular DO clitic pronoun after verbal -s. Reference example: Ese xato, ¿véndeslo tu? 'This calf, do you sell it?'.

6. Secondary forms of the 3rd person masculine singular DO clitic pronoun after verbal $-\boldsymbol{n}$. Reference example: Ese viño véndenlo ali 'That wine, they buy it there'.

For phenomena 4, 5 and 6 several variations in gender and number are observed in the original questionnaire, although for the specific aims of this paper the reference of masculine singular is considered to be enough. In those cases, three assumptions are proposed:

- Formal variants of the pronoun, generated through contact with $-r,-s$ or $-n$.

- Contrast between primary and secondary forms; depending on the territories studied, the above-mentioned formal variants may appear as unique forms or as secondary forms to other forms in a free context.

- Events on the final verbal consonant when followed by the pronoun (loss or maintenance): infinitive $-r$, 2nd person singular $-s$, 3rd person plural $-n$.

The dialectographic maps obtained will be considered alongside these three assumptions in all cases. For practical purposes, the well-known isogloss «conservation || diphthongisation of short $\breve{E}, \mathrm{O} »$ has been represented in the maps as a discontinuous thin line, since this isogloss, together with some other which are located quite close to it, has served as a border reference between both domains in our dialectological tradition. The pronominal isoglosses discussed in this paper are shown as continuous thick lines.

\section{Masculine singular in a free context}

The following variants can be distinguished: 


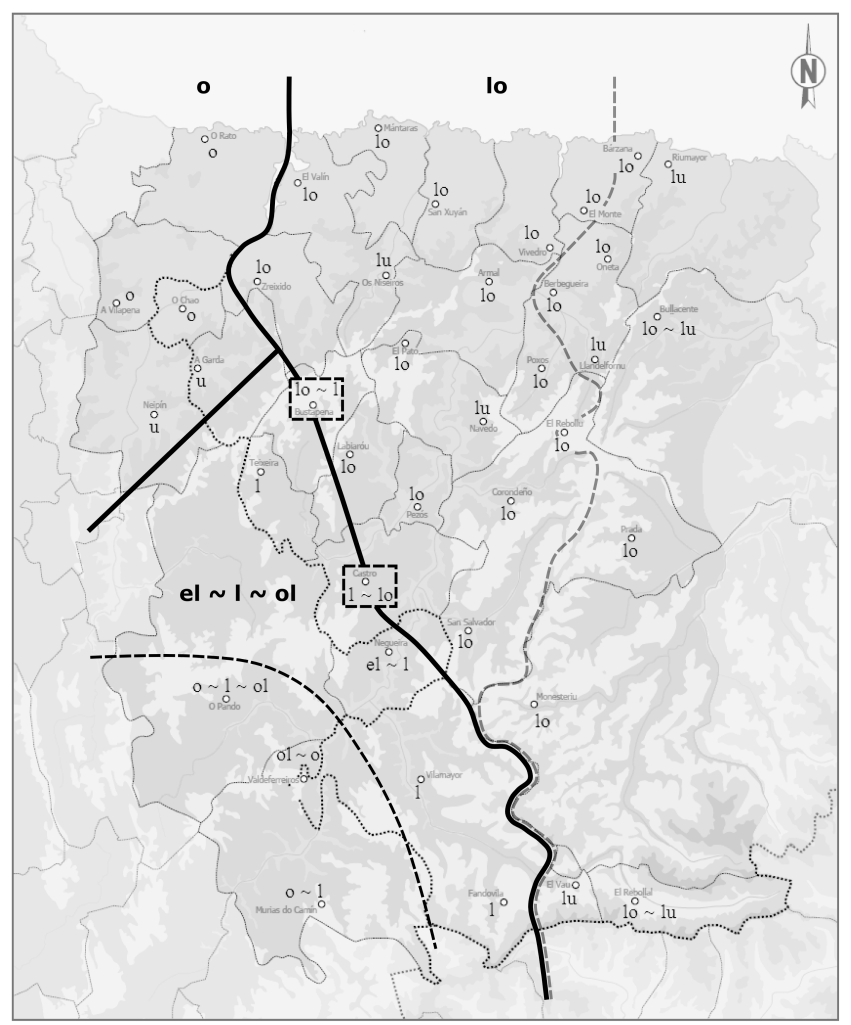

Map 1. Primary forms of the 3rd person masculine singular DO clitic pronoun (in a postvocalic context)

- North-western variant $o \sim u$. Located in one of the westernmost parts of the area studied and in continuity with the general solution of Galician-Portuguese; it only affects five areas (three of them in the province of Lugo).

- South-eastern variant $e l \sim I \sim$ ol. This feature of a part of Eastern Galician penetrates the western and south-western area of the Eo-Navia.

- Eastern variant $l o \sim l u$. It occupies the largest part of the territory studied, extending west of the classic isogloss, especially towards the northern and central areas, in continuity with Astur-Leonese. Despite this, it coincides with such isogloss in its southernmost stretch.

The villages of Bustapena (Vilanova) and Castro (Grandas), in which the variants I and $l o$ coexist have been highlighted in two rectangular boxes. In the south-western angle of the area studied, O Pando (A Fonsagrada), Valdeferreiros (Ibias) and Murias do Camín (Navia de Suarna) have also been distinguished as an area where the variants $I \sim o l$ and $o$ alternate.

The isoglosses follow a general north-to-south direction, as it is common in the 
Dialectologia. Special issue, $\boldsymbol{V}$ (2015), 219-240.

ISSN: 2013-2247

linguistic borders of the Eo-Navia territory.

\section{Feminine singular in a free context}

The following variants can be distinguished:

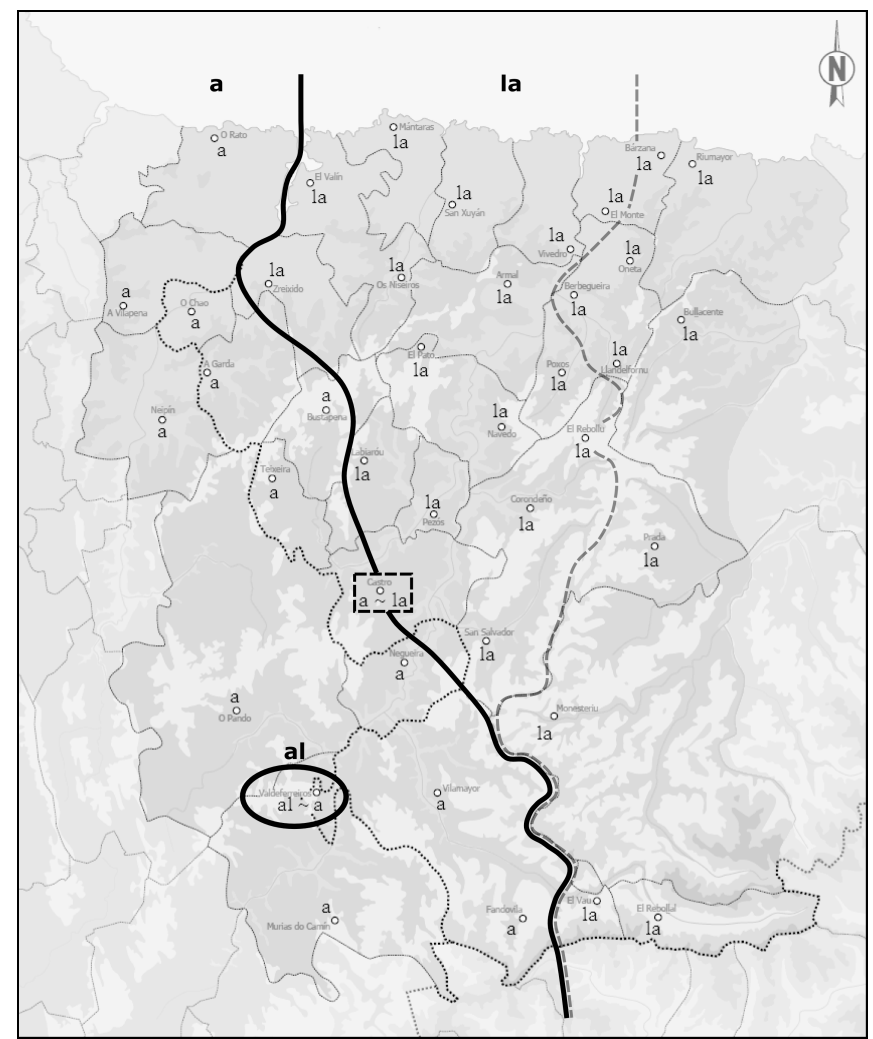

Map 2. Primary forms of the 3rd person feminine singular DO clitic pronoun (in a postvocalic context)

- Western variant $a$. Its area basically coincides with the sum of the $o \sim u$ and the $e l \sim l \sim o l$ areas of the masculine singular pronoun, stretching along the western and south-western parts of the area studied, in continuity with Galician-Portuguese. ${ }^{2}$

- Eastern variant $l a$. It occupies the same areas as the masculine $l o \sim l u$, that is, the largest part of the Eo-Navia in continuity with Astur-Leonese.

- South-western variant al. It has only been registered in the village of Valdeferreiros (Ibias), alternating with the typical form of the surrounding area (a).

\footnotetext{
${ }^{2}$ In Fandovila (Ibias) this pronominal $a$ variant, when preceded by /a/, alternates with an oa [oa] form, which presents the insertion of a semivocalic antihiatic segment: Xa a cantou 'He already sang it' versus Péchaoa 'Close it'.
} 
The village of Castro (Grandas), where $a$ and la alternate, has also been highlighted by a rectangular box.

The main isogloss continues to follow a general north-south direction. In its northern and central stretch, its trajectory moves further to the west than that of the reference isogloss, while in its southern stretch, both converge

\section{Masculine plural in free context}

A western variant os $\sim$ us and an eastern variant los $\sim$ lus, can be observed and their areas coincide with those of $a$ and $l a$ in the previous map. The same observations done in the previous case can be made in this instance regarding the positioning of the isogloss and the data given previously about its location with respect to the reference isogloss also apply here.

The village of Castro (Grandas) is highlighted once more, for it is here that the forms os and los alternate.

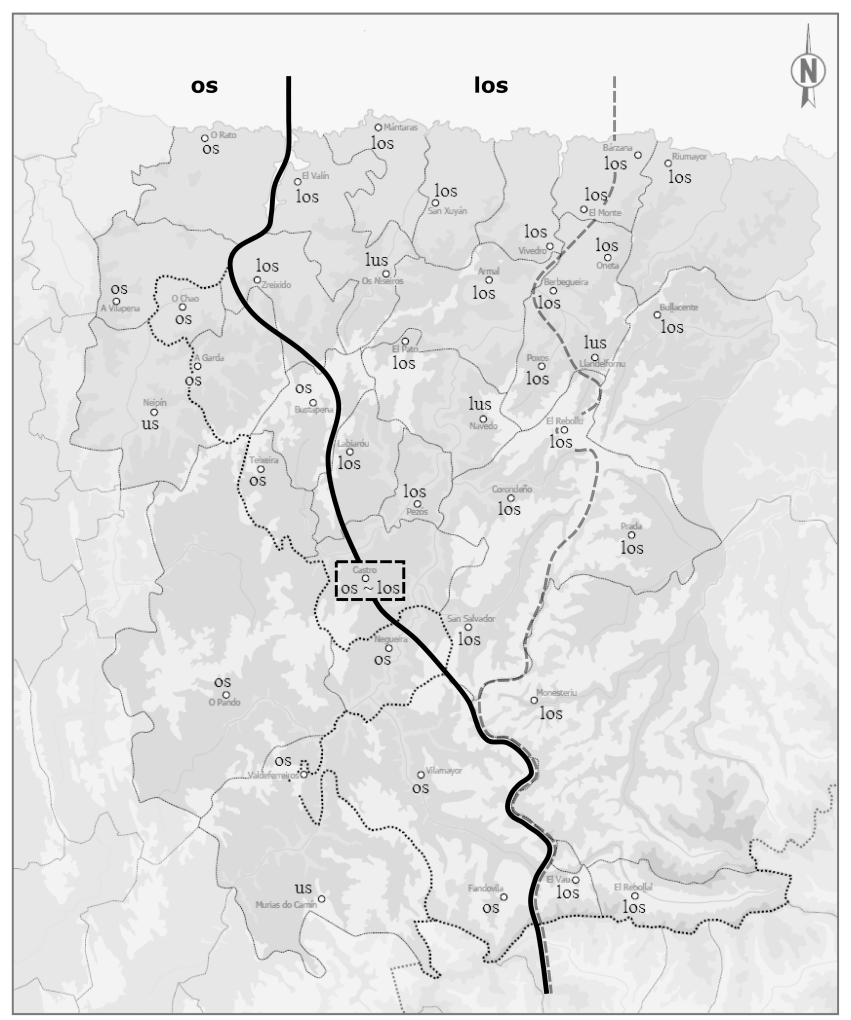

Map 3. Primary forms of the 3rd person masculine plural DO clitic pronoun (in a postvocalic context) 
Dialectologia. Special issue, $\boldsymbol{V}$ (2015), 219-240.

ISSN: 2013-2247

\section{Masculine singular after verbal $-r$}

In all cases, verbal $-r$ corresponds to the infinitive form. It is to be taken into account that, in all of the maps that follow, the masculine singular form, in fact, represents the gender and number variations of the DO pronoun.

\subsection{Formal variants of the pronoun}

The relevant information in this map is the form of the pronoun (the annotations [sí], [non] and [sí/non] refer to the existence or non-existence of secondary forms as opposed to the primary forms, an issue which will be dealt with in subsequent sections).

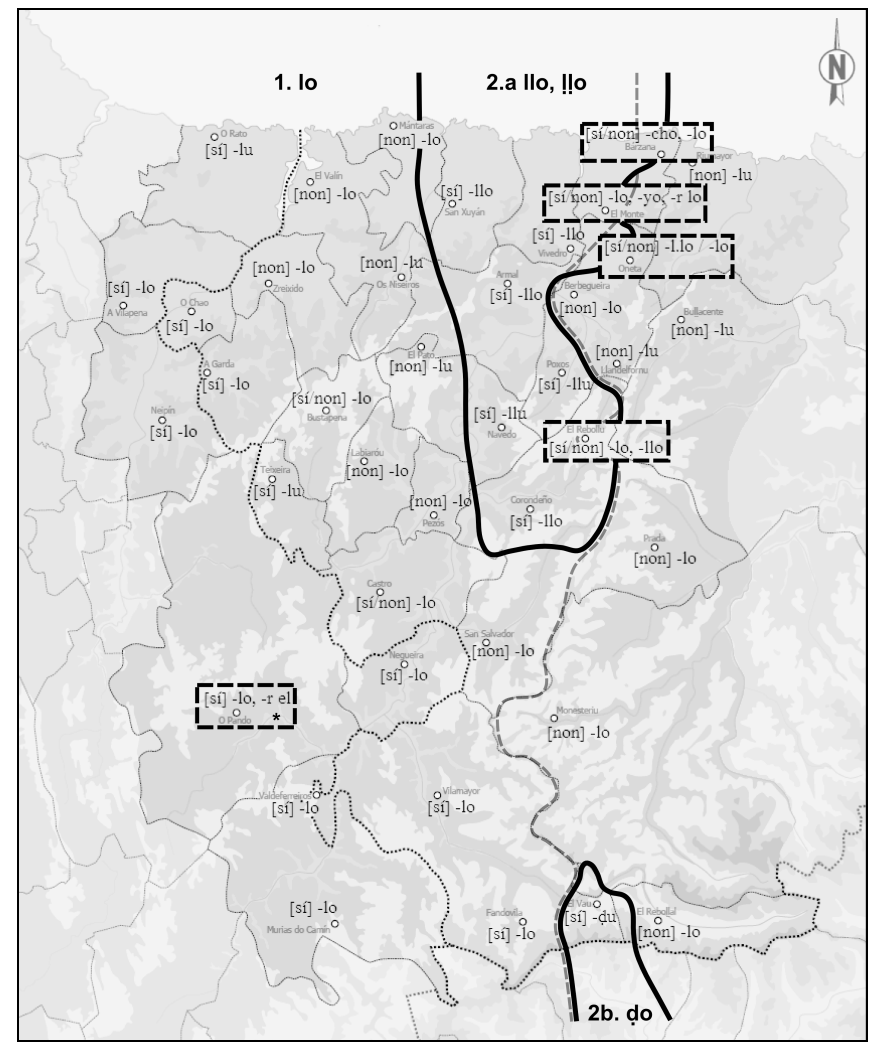

Map 4. Forms of the 3rd person masculine singular DO clitic pronoun after infinitive verbal $-r$

In view of the map, the following geolectal areas can be distinguished: 
- Area (1) lo lu, which occupies the largest part of the area studied, in a continuum only interrupted by zones $2 \mathrm{a}$ and $2 \mathrm{~b}$. In this area speakers say $Q u(i) e r o$ vendelo 'I want to sell it'. This area corresponds to $l o \sim l u$, regardless of whether it is the secondary form in relation to a primary form (a feature contemplated on Map 5).

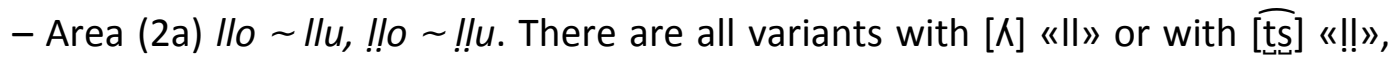
and their geographical distribution attends to two types of palatalization which shall not be discussed in this instance. In this area, speakers say Qu(i)ero vendello or Quiero vendel! 0 . The rectangular boxes show villages and towns where a coexistence between these forms and lo $\sim / u$ has been registered. As Map 5 will show, the palatalised forms always operate as secondary forms to $l o \sim l u$.

- Area (2b) do $\sim d u$. This is the palatalised voiced variant [d] («ḍ). Speakers in this area say Quiero vendedu. Area $2 \mathrm{~b}$ presents territorial continuity with a different $/ / o$ $\sim$ Ilu area which stretches south, in the adjacent part of the province of León.

The spatial disposition of areas (2a) and (2b) seems to suggest that there is a geographical continuity broken only by area (1). It is necessary to emphasize that areas (2a) and (2b) are, in turn, discontinuous with respect to other $(-r)+\|l o \sim\| u$ and $(-r)+$ !lo !lu areas, which are located further east, inside Asturias and León.

The villages of Bárzana (Navia), El Monte (Navia), Oneta (Villayón) and El Rebollu (Ayande) are highlighted with rectangular boxes, for it is here that alternating between type 1 and type 2a forms, located thus in the border between both areas, can be found. The village of $O$ Pando (A Fonsagrada) is also highlighted, for it is here that 10 and $e l$ alternate, with maintenance of $-r$ in the second case.

\subsection{Contrast between primary and secondary forms}

If the phenomenon under study in this case is the possession of primary and secondary forms (marked as [sí] on Map 4), in contrast to the possession of unique forms (marked on Map 4 as [non]), the resulting map is the following one, where the previously-known linguistic information is disposed of. 


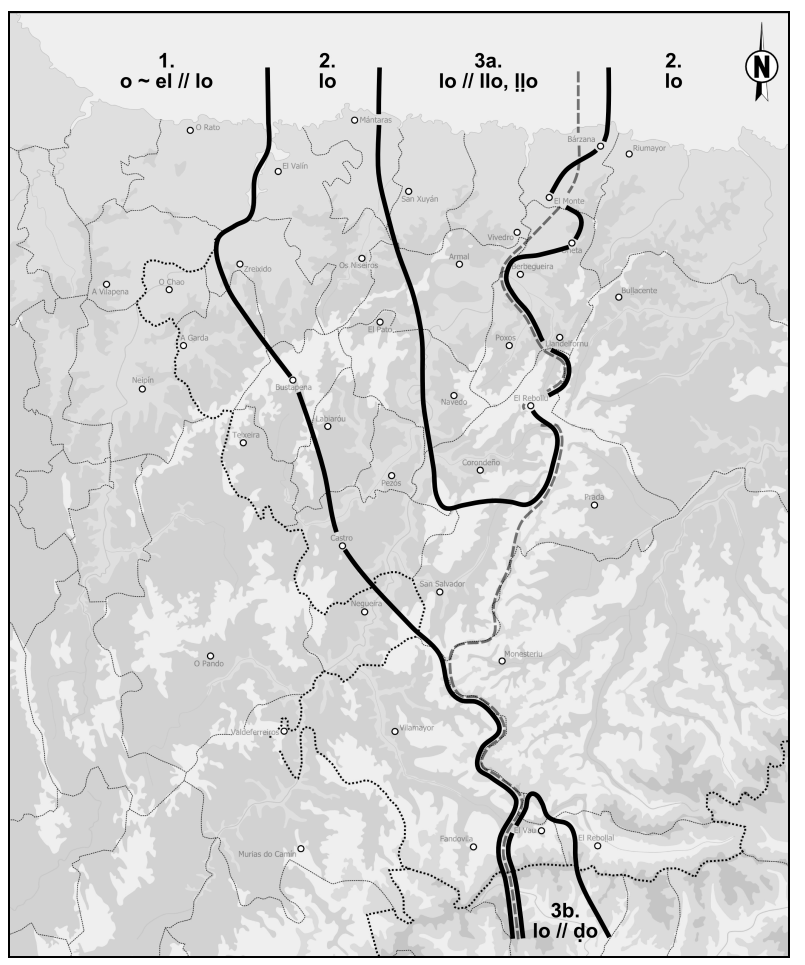

Map 5. Primary forms and secondary forms of the $3^{\text {rd }}$ person masculine singular DO clitic pronoun after verbal $-r$

This map synthesises and combines the information presented in Maps 1 and 4; thus the territory under study is divided into four areas:

- Area (1), with primary forms $o \sim u$ or $e l \sim l \sim o l$ and the secondary form $l o \sim l u$. Speakers in the area say Sempre o vendes or Sempre el vendes 'You always sell it', but Quero vendelo 'I want to sell it'.

- Area (2), with lo lu as pronominal unique form, both following a vowel and after verbal $-r$. In this area speakers say S(i)empre lo v(i)endes and Qu(i)ero vendelo.

- Area (3a), with the primary form $l o \sim / u$ and secondary palatalised forms $/ l o \sim$ Ilu or !lo $\sim$ !lu, depending on the location. Speakers in this area say: S(i)empre lo v(i)endes, but Qu(i)ero vendello or Quiero vende!!u.

- Area (3b), with the primary form $l o \sim / u$ and the palatalised secondary form do $\sim d u$. Speakers in the area say Siempre lu viendes, but Quiero vendedu.

In table 2 an outline of the information displayed in the previous map can be found: 


\begin{tabular}{|c|c|c|c|c|}
\hline & AREA 1 & AREA 2 & AREAS 3A, 3B & AREA 2 \\
\hline PRIMARY FORMS & $\begin{array}{l}\mathrm{O} \sim \mathrm{U}, \mathrm{EL} \sim \mathrm{L} \sim \mathrm{OL} \\
\text { Sempre o vendes } \\
\text { Sempre el vendes }\end{array}$ & \multirow[b]{2}{*}{$\begin{array}{l}\text { LO LU } \\
\text { Siempre lo vendes } \\
=\text { Quero vendelo }\end{array}$} & $\begin{array}{l}\text { LO LU } \\
\text { S(i)empre lo v(i)endes }\end{array}$ & \multirow[b]{2}{*}{$\begin{array}{l}\text { LO LU } \\
\text { Siempre lu viendes } \\
=\text { Quiero vendelu }\end{array}$} \\
\hline $\begin{array}{l}\text { SECONDARY } \\
\text { FORMS AFTER- } R\end{array}$ & $\begin{array}{l}\mathrm{LO} \sim \mathrm{LU} \\
\text { Quero vendelo }\end{array}$ & & $\begin{array}{l}\text { LLO LLU, } \\
\text { LLOO LLU (DU) } \\
\text { Qu(i)ero vendello } \\
\text { Quiero vende!lu (-ḍu) }\end{array}$ & \\
\hline
\end{tabular}

Table 2. Geodistribution of the allomorphs of the DO clitic pronoun after vowel and after verbal $-r$

Areas $3 a$ and $3 b$ could then be considered to be discontinuous penetrations of the Galician-Portuguese feature which consists on presenting secondary forms after $-r$. Parallel to this, it can be concluded that area 2, in its westernmost stretch, is a penetration of the Astur-Leonese feature which consists on the absence of secondary forms after $-r$.

\subsection{Events on the final verbal consonant}

Finally, if not only the form of the pronoun but the set made up from the sequence infinitive $-r+$ pronoun is taken into consideration, the complete territory of study would become a unique area, since the disappearance of $-r$ would be confirmed throughout. Nonetheless, in certain spots in El Monte (Navia) or O Pando (A Fonsagrada) the disappearance of $-r$ before a pronoun can alternate with cases of maintenance, such as vendelo $\sim$ venderlo in the first case and vendelo $\sim$ vendérel in the second.

\section{Masculine singular after verbal -s}

In all cases verbal -s corresponds to the 2 nd person singular.

\subsection{Formal variants of the pronoun}

From the point of view of the form the pronoun adopts after verbal $-s$, it is obvious that the territory studied constitutes a unique area with no geodifferential 
Dialectologia. Special issue, $\boldsymbol{V}$ (2015), 219-240.

ISSN: 2013-2247

features, since $10 \sim 14$ appears as an exclusive option in the 40 geographical points where the questionnaire was applied.

\subsection{Contrast between secondary and primary forms}

If the existence or absence of the primary and secondary forms is considered in contrast to the existence of a unique form, two areas will result:

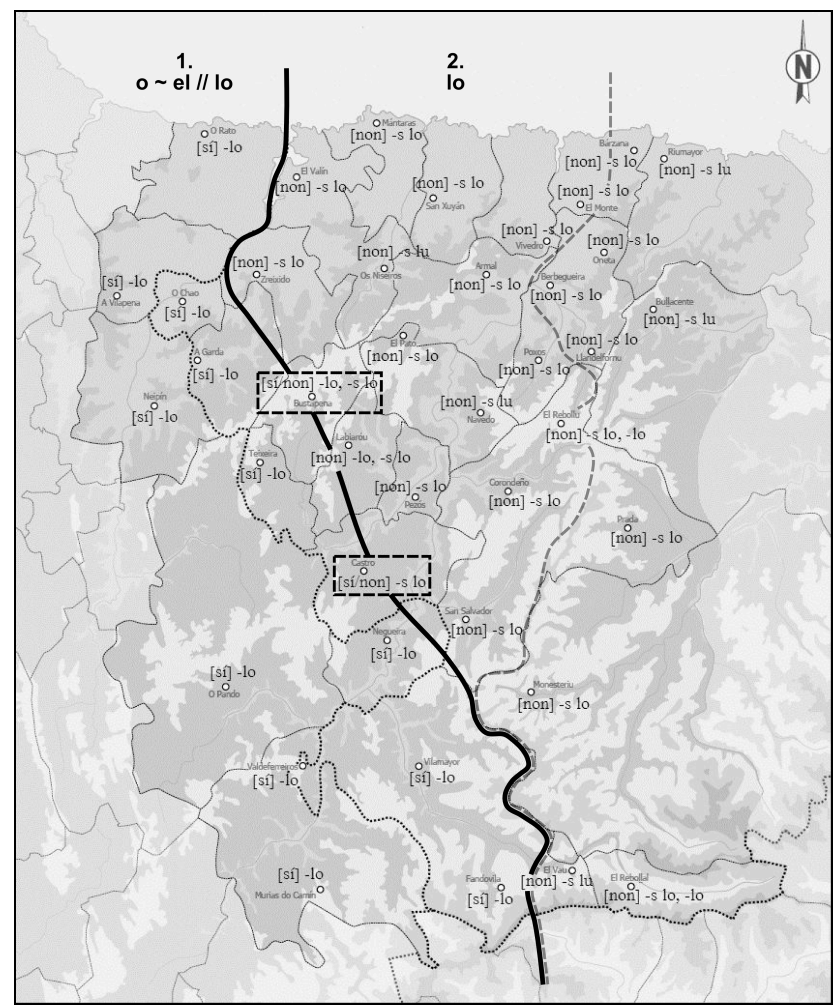

Map 6. Forms of the 3rd person masculine singular DO clitic pronoun after 2nd person singular verbal -s

- Area (1), with a distinction between primary and secondary forms (marked in the map as [sí]).

- Area (2), which presents only unique forms (marked in the map as [non]).

The rectangular boxes highlight the localities of Bustapena (Vilanova) and Castro (Grandas), where the form lo $\sim l u$ works both as secondary form to the primary $I$, and as a unique form, since both coexist in a postvocalic context (Veríalo $\sim$ Veríal 'He would see it'). 
The map presented previously can be summarised in the outline presented on Table 3.

\begin{tabular}{|c|c|c|}
\hline & AREA 1 & AREA 2 \\
\hline PRIMARY FORMS & $\begin{array}{l}\mathrm{O} \sim \mathrm{U}, \mathrm{EL} \sim \mathrm{L} \sim \mathrm{OL} \\
\text { Sempre o vendes 'You } \\
\text { always sell it' } \\
\text { Sempre el vendes }\end{array}$ & $\begin{array}{l}\text { LO LU } \\
\text { Sempre lo vendes, } \\
\text { Siempre lu viendes } \\
\text { = Vénde }(s) l o \text { sempre, }\end{array}$ \\
\hline $\begin{array}{l}\text { SECONDARY } \\
\text { FORMS-S }\end{array}$ & $\begin{array}{l}\text { LO LU } \\
\text { Véndelo sempre }\end{array}$ & Viéndeslu siempre \\
\hline
\end{tabular}

Table 3. Geodistribution of the allomorphs of the DO clitic pronoun after verbal $-s$

The isogloss separating both areas almost coincides with the isogloss separating the areas of western pronominal $a$ forms from the areas with la form (Map 2) or those areas where os $\sim$ us is used versus the areas with los $\sim$ lus (Map 3). The eastern area then extends significantly further west of the reference isogloss in the northern and central part of the Eo-Navia, to then be joined with the afore-mentioned reference isogloss in its southernmost stretch.

\subsection{Events on the final verbal consonant}

If the phenomenon considered is the occurrence of verbal $-s$, two areas are to be distinguished:

- Western area $(-s)+l o \sim l u$, with loss of verbal -s: Véndelo 'You sell it'.

- Eastern area -s + lo / $\mathrm{l}$, with maintenance of verbal -s: Véndes/o, Viéndes/u. 


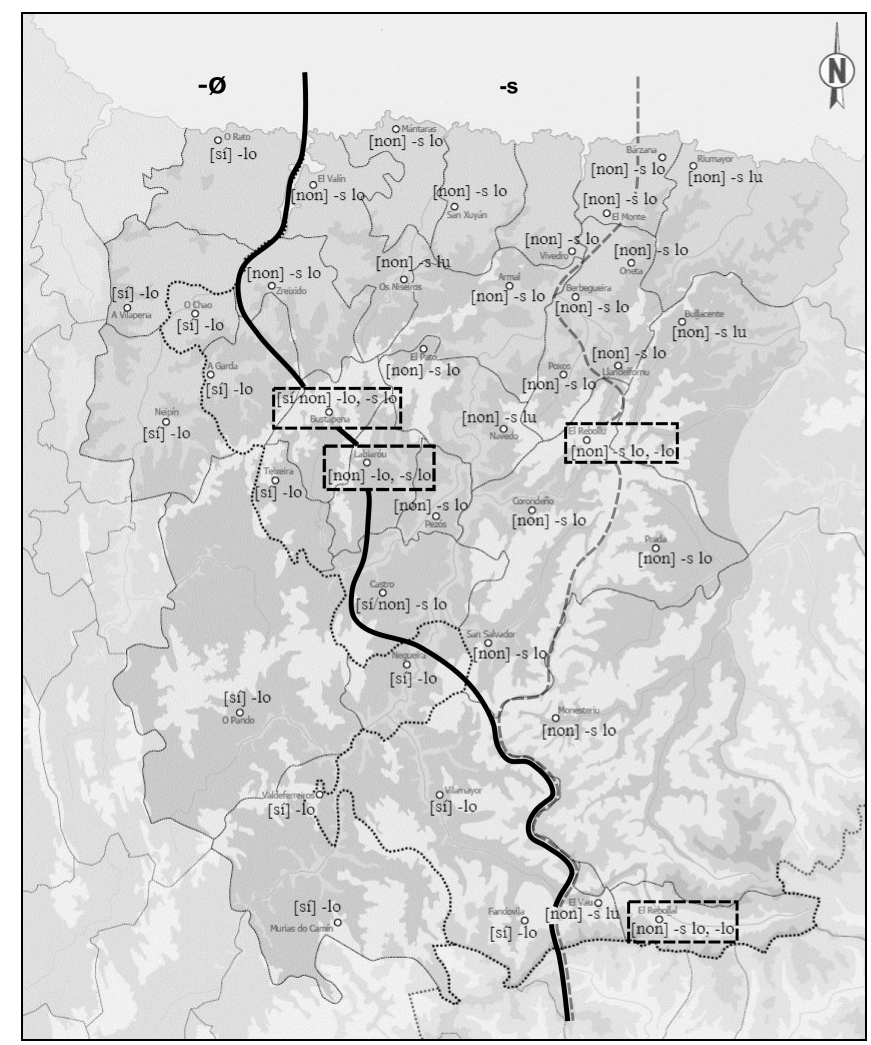

Map 7. Maintenance or loss of the 2 nd person singular verbal $-s$ with the 3 rd person DO clitic pronoun

The villages of Bustapena (Vilanova), Labiaróu (Samartín), El Rebollu (Ayande) and El Rebol!al (Degaña) are highlighted within rectangular boxes, as areas which alternate the loss of the 2nd person singular $-s$ with its maintenance: Véndelo or Véndes/o.

\section{Masculine singular after verbal $-n$}

In all cases, verbal $-n$ corresponds to the $3^{\text {rd }}$ person plural.

\subsection{Formal variants of the pronoun}

According to the pronominal form, three areas can be appreciated in the map:

- Western area no nu, where speakers say Véndeno [-no] 'They sell it' with an alveolar nasal sound.

-Eastern area lo $\sim / u$, where speakers say $V(i) e ́ n d e n l o$. 
- South-western area nol [-nol] with an alveolar nasal sound, corresponding with the village of Valdeferreiros (Ibias): Véndenol, alternating with no (Véndeno).

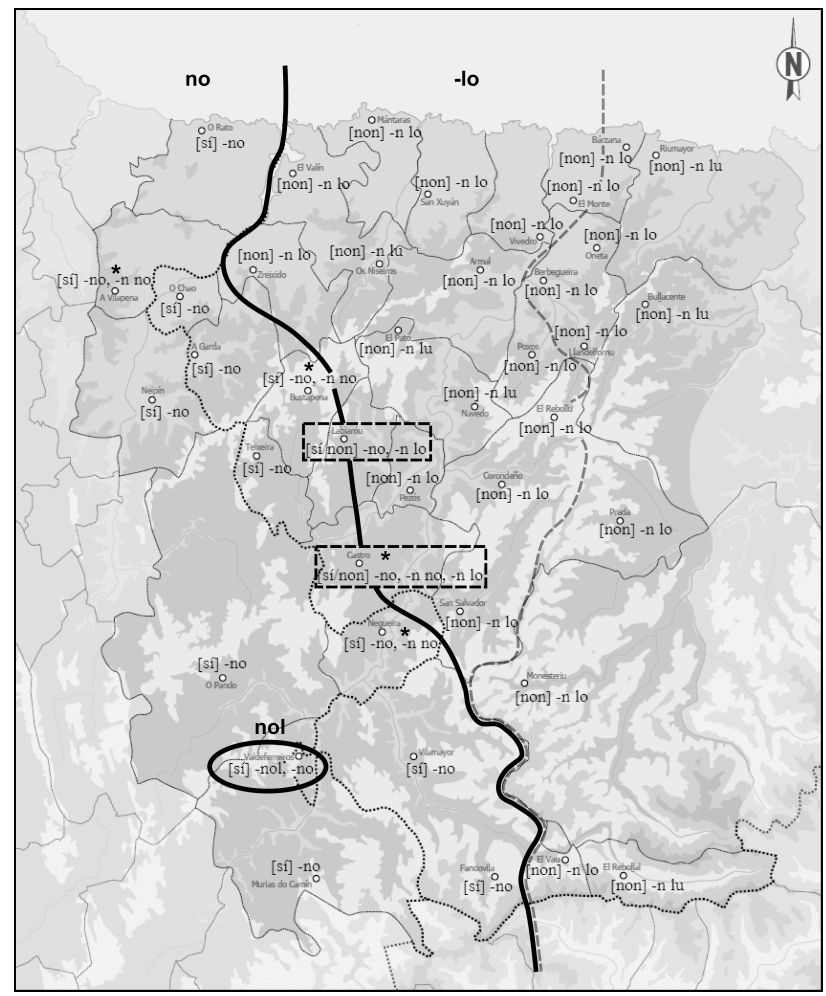

Map 8. Forms of the 3rd person DO clitic pronoun after 3rd person plural verbal $-n[-n]$

The villages of Labiaróu (Samartín) and Castro (Grandas) are highlighted within rectangular boxes, as areas alternating no $\sim n u$ and $l o \sim l u$; thus, Véndeno or Véndenlo. It should also be pointed out that in the south-western area formed by Valdeferreiros (Ibias) the privative form of this region (nol) alternates with that of the surrounding area (no).

\subsection{Contrast between primary and secondary forms}

If the phenomenon studied is the existence or absence of secondary forms (marked in the map with [sí]) or the existence of unique forms (marked in the map with [non]), the previously-mentioned western and eastern areas coincide completely, and the south-western area (Valdeferreiros) would be inscribed into the western one. That is: 
Dialectologia. Special issue, $\boldsymbol{V}$ (2015), 219-240.

ISSN: 2013-2247

- Western area with secondary forms no $\sim$ nu or nol, corresponding to the primary forms $o \sim u$ or $e l \sim o l \sim l$.

- Eastern area with a unique form $l o \sim / u$.

\subsection{Events on the final verbal consonant}

A new coincidence with the previous areas occurs in this case:

- Western area with forms no $\sim$ nu or nol that imply the loss of verbal $-n[-\eta]$. Notable exceptions are A Vilapena (Trabada), Bustapena (Vilanova), Castro (Grandas) and Negueira (Negueira), where the loss of the final verbal consonant alternates with its maintenance: Véndeno [-ño] or Véndenno. ${ }^{3}$

- Eastern area with forms $10 \sim 1 u$ which imply the maintenance of verbal $-n$ : V(i)éndenlo.

All aspects related to the meeting of the final verbal $-n$ with the 3rd person masculine singular DO pronoun, are presented as an outline in Table 4:

\begin{tabular}{|c|c|c|}
\hline & WESTERN AREA & EASTERN AREA \\
\hline PRIMARY FORMS & $\begin{array}{l}\mathrm{O} \sim \mathrm{U}, \mathrm{EL} \sim \mathrm{L} \sim \mathrm{OL} \\
\text { Sempre o venden 'You } \\
\text { always sell it' } \\
\text { Sempre el venden }\end{array}$ & \multirow{3}{*}{$\begin{array}{l}\text { LO LU } \\
\text { S(i)empre lo v(i)enden } \\
=V \text { (i)éndenlo s(i)empre }\end{array}$} \\
\hline \multirow{2}{*}{$\begin{array}{l}\text { SECONDARY } \\
\text { FORMS AFTER - } N\end{array}$} & $\begin{array}{l}\text { NO NU } \\
\text { Véndeno sempre } \\
\text { (Véndenno sempre) }\end{array}$ & \\
\hline & $\begin{array}{l}\text { NOL } \\
\text { Véndenol sempre }\end{array}$ & \\
\hline
\end{tabular}

Table 4. Geodistribution of the allomorphs of the DO clitic pronoun after verbal $-n$

\footnotetext{
${ }^{3}$ This pronominal form -no after maintained final $-n$ also appears in Negueira (Negueira) and Fandovila (Ibias) after non-verbal - $n$ : Nono vexo ben or Non no vexo ben 'I don't see him $\sim$ it well', Nuna vin or Nun na vin 'I didn't see her'.
} 


\section{Conclusions}

In view of the geolectal data presented in this paper, the team has reached several conclusions after the research:

1. As regards the pronominal phenomena studied, the isoglosses show a predominant north-south direction, in a similar fashion to the majority of isoglosses present in the area.

2. The pronominal isoglosses described in this paper have been revealed to be part of the bundle of isoglosses existing in the border between Galician-Portuguese and Astur-Leonese and should, consequently, be incorporated to it.

3. Regarding the allomorphs of the clitic pronouns under consideration in this paper and in light of the data gathered in the study, it can be concluded that the greatest part of Galician-Asturian ascribes to the Eastern geotypology, i.e. the AsturLeonese. The Eastern typology (Galician-Portuguese), on the other hand, appears in the westernmost territories.

\section{References}

ALonso, Dámaso (1972-1993) Obras completas, Madrid: Gredos.

Álvarez-Balbuena García, Fernando, Ramón de Andrés Díaz, Xosé Miguel Suárez Fernández \& María Cueto Fernández (2011) "La 'horiometría' o dialectometría de frontera", in IX Congreso Internacional de Lingüística General. 21-23 de junio de 2010. Universidad de Valladolid. Actas del congreso, Valladolid: Universidad de Valladolid / Junta de Castilla y León / Instituto Castellano y Leonés de la Lengua / Ayuntamiento de Valladolid / Diputación de Valladolid, 107-134.

ANDRÉS DíAZ, Ramón de (2011) “Fronteras lingüísticas y geotipos, con atención a la zona EoNavia”, in R. de Andrés Díaz (coord.), Lengua, ciencia y fronteras, Uviéu: Ediciones Trabe / Universidá d’Uviéu (Seminariu de Filoloxía Asturiana), 121-152.

ANDRÉS DíAZ, Ramón de (2013) "Tractament horio- i dialectomètric de noves isoglosses a la frontera entre el galaico-portuguès i l'asturlleonès", in E. Casanova Herrero \& Cesáreo Calvo Rigual (eds.), Actas del XXVI Congreso Internacional de Lingüística y de Filología Románica (Valencia, 2010), vol. VI, Berlin: De Gruyter, 41-52. 
Dialectologia. Special issue, V (2015), 219-240.

ISSN: 2013-2247

Andrés Díaz, Ramón de \& Fernando Álvarez-Balbuena García (2011) “Projecte ETLen de mesurament de la frontera entre els dominis asturlleonès i galaicoportuguès", in G. Colón Domènech \& L. Gimeno Betí (eds.), Noves tendències en la dialectologia contemporània, Castelló de la Plana: Universitat Jaume I, 205-232.

Andrés Díaz, Ramón d', Fernando Álvarez-Balbuena García \& Xosé Miguel SuÁrez Fernández (2007) “Proxecto ETLEN para o estudio dialectográfico e dialectométrico da zona EoNavia, Asturias: fundamentos teóricos", in H. González Fernández \& M. X. Lama López (dirs.), Actas do VII Congreso Internacional de Estudos Galegos. Mulleres en Galicia. Galicia e os outros pobos da Península. Barcelona 28 ó 31 de maio de 2003, Sada: Ediciós do Castro, 749-759.

Andrés Díaz, Ramón de, Fernando Álvarez-Balbuena García, María Cueto Fernández \& Xosé Miguel SUÁREZ FERNÁNDEZ (2012) “Frontières linguistiques et horiométrie. La transition linguistique de l'interfluve Eo-Navia (Asturies) et le projet ETLEN", in X. A. Álvarez Pérez, E. Carrilho \& C. Magro (eds.), Proceedings of the International Symposium on Limits and Areas in Dialectology (LimiAr). Lisbon, 2011, Lisboa: Centro de Linguística da Universidade de Lisboa, 1-21.

Andrés díaz, Ramón de, Fernando Álvarez-Balbuena García, María Cueto Fernández \& Xosé Miguel SUÁREZ FeRnÁNDEZ (2013) “About the Concept of 'Geodifferential Feature' between Linguistic Varieties in Contact", in E. Carrilho, C. Magro \& X. A. Álvarez (eds.), Current Approaches to Limits and Areas in Dialectology, Newcastle upon Tyne: Cambridge Scholars Publishing, 85-122.

BabarRo González, Xoán (2003) Galego de Asturias. Delimitación, caracterización e situación sociolingüística, [A Coruña]: Fundación Pedro Barrié de la Maza.

Cueto Fernández, María (2012) “Continuidad y geotipificación en la frontera lingüística del gallego y el asturiano", Interlingüística, 22 (1), 295-309.

FeRnÁNDEZ ReI, Francisco (1990) Dialectoloxía da lingua galega, Vigo: Edicións Xerais de Galicia. FERNÁNDEZ VIOR, José Antonio (1997) El habla de Vegadeo (A Veiga y su concejo), Uviéu: Academia de la Llingua Asturiana.

FerReIRO, Manuel (1996) Gramática Histórica Galega (Manual), Santiago de Compostela: Edicións Laiovento.

FRíAS CONDE, Xavier (2001) "Os límites entre galego e asturleonés en Asturias", Revista de Filología Románica, 18, 51-71. 
García, Constantino (dir.), Antón Santamarina (dir.) \& Rosario Álvarez Blanco (coord.) (1995) Atlas Lingüístico Galego. Volume II. Morfoloxía non verbal, A Coruña: Fundación "Pedro Barrié de la Maza, Conde de Fenosa".

García, Constantino (dir.), Antón Santamarina (dir.), Rosario Álvarez Blanco (coord.), Francisco DUbert García (coord.) \& Xulio César SOUSA Fernández (coord.) (2005) Atlas Lingüístico Galego. Volume V. Léxico. O ser humano (I), A Coruña: Fundación Pedro Barrié de la Maza.

García, Constantino (dir.), Antón Santamarina (dir.) \& Francisco Fernández Rei (coord.) (1990) Atlas Lingüístico Galego. Volume I. Morfoloxía Verbal, A Coruña: Fundación "Pedro Barrié de la Maza, Conde de Fenosa".

García, Constantino (dir.), Antón Santamarina (dir.) \& Francisco Fernández Rel (coord.) (2003) Atlas Lingüístico Galego. Volume IV. Léxico. Tempo atmosférico e cronolóxico, A Coruña: Fundación Pedro Barrié de la Maza.

García, Constantino (dir.), Antón Santamarina (dir.) \& Manuel González González (coord.) (1999) Atlas Lingüístico Galego. Volume III. Fonética, A Coruña: Fundación “Pedro Barrié de la Maza, Conde de Fenosa".

GARCía ARIAS, Xosé Lluis (2002-2004) Diccionario general de la lengua asturiana, Oviedo: Editorial Prensa Asturiana S.A. / La Nueva España.

García GarcíA, José (1983) El habla de El Franco (una variante lingüistica del Occidente de Asturias), Mieres del Camín: Instituto «Bernaldo de Quirós».

HEAP, David (2003) Linguistic Atlas of the Iberian Peninsula, [London, ON]: University of Western Ontario. [http://westernlinguistics.ca/alpi/]. <04.02.2015>.

MuÑIz, Celso (1978) El habla del Valledor - Estudio descriptivo del gallego asturiano de Allande (Asturias - España), Amsterdam: Academische Pers.

SANTAMARINA, Antón (ed.) (2003) Diccionario de diccionarios. Versión 3.0., [A Coruña]: Fundación Pedro Barrié de la Maza.

WILLIAMS, Edwin Bucher (1994) Do latim ao português. Fonologia e morfologia históricas da língua portuguesa, Rio de Janeiro: Edições Tempo Brasileiro. 